\title{
Xanthomonas vesicatoria in Puerto Rico
}

\section{J. Enrique Pérez and Amelia C'ortés-Monllor ${ }^{1}$ \\ INTRODUCTION}

During the summer of 1960 tomato leaves and fruits with symptoms highly suggestive of scab spot were collected in Jayuya by the Station Director and brought to the laboratory for study. Later on, Dr. Frederick L. Wellman also brought to the laboratory a few tomato fruits with lesions which were tentatively diagnosed as those of scab spot. These tomatoes came from an experimental plot at the Isabela Substation.

Since scab spot of tomato has never before been reported from Puerto Rico, studies were carried out to confirm its existence in the Island. This paper reports the results of these studies.

\section{MATERIALS AND METHODS}

\section{SOURCE OF INFECTED MATERIAL}

Green tomatoes of the variety Manalucie bearing scab lesions about 3 $\mathrm{mm}$. in size were brought to the laboratory. The lesions were crateriform in shape and had a raised center (fig. 1, A). Material was also obtained from leaves showing brown spots.

\section{ISOLATION PROCEDURE}

Isolation was performed in either of two ways: $1, \mathrm{By}$ using a sterile inoculating needle material from a single lesion was scraped and inoculated to nutrient broth, or 2, a circular cut surrounding the lesion was made with a sterilized scalpel, and the whole piece of tissue removed. Two or three such pieces of tissue were placed in a sterile mortar and ground with a little sterile sand. About $1 \mathrm{ml}$. of nutrient broth was then added and from 0.05 to $0.1 \mathrm{ml}$. of the resulting suspension was aseptically pipetted to tubes of nutrient broth and streaked on Nutrient Agar (Difco) plates. Material from leaves showing the brown spots was also ground in mortars and similarly treated. ${ }^{2}$

1 Bacteriologist, and Research Assistant in Bacteriology, respectively, Agricultural Experiment Station, University of Puerto Rico, Río Piedras, P.R.

2 Cultures of all samples yielded the same organism. Only one of the cultures obtained from the scab spots on fruits was run through all tests herein reported. Therefore, only the studies with this organism (isolate No. 98) are included in this report. 


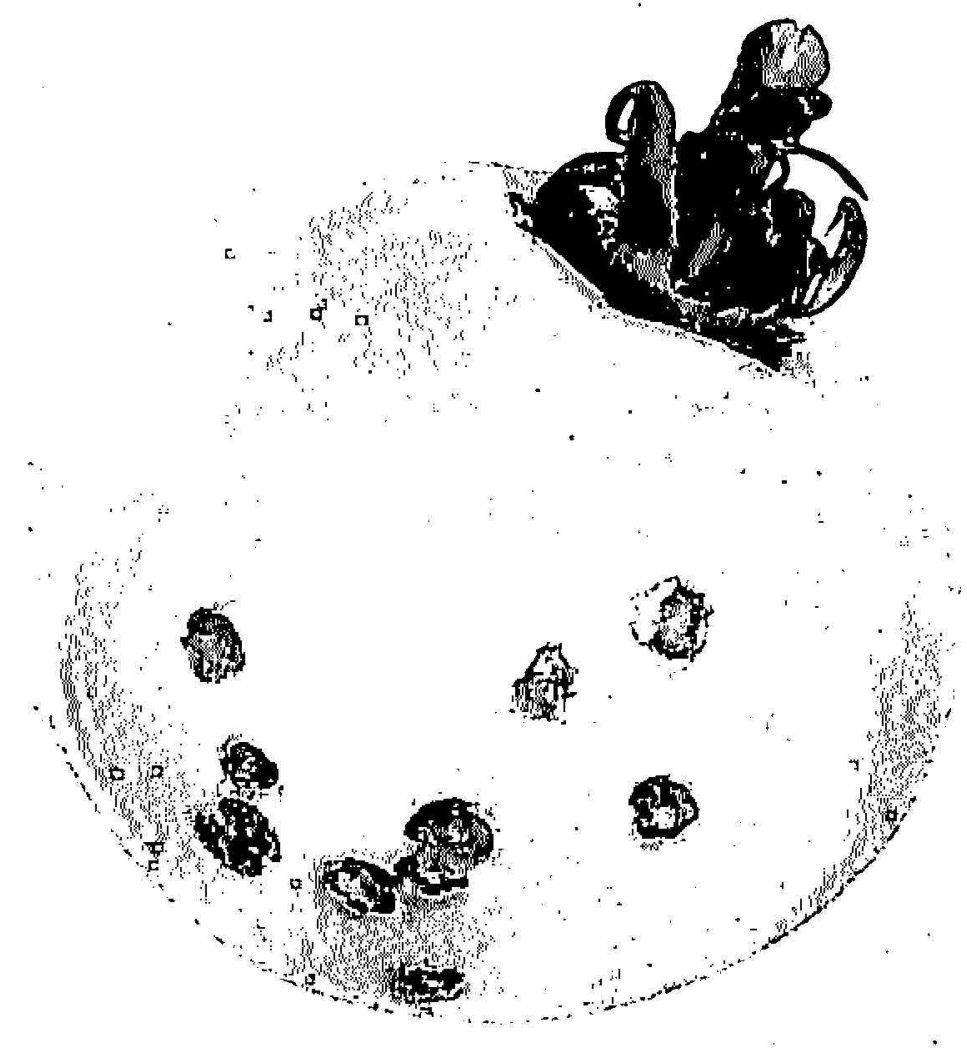

A

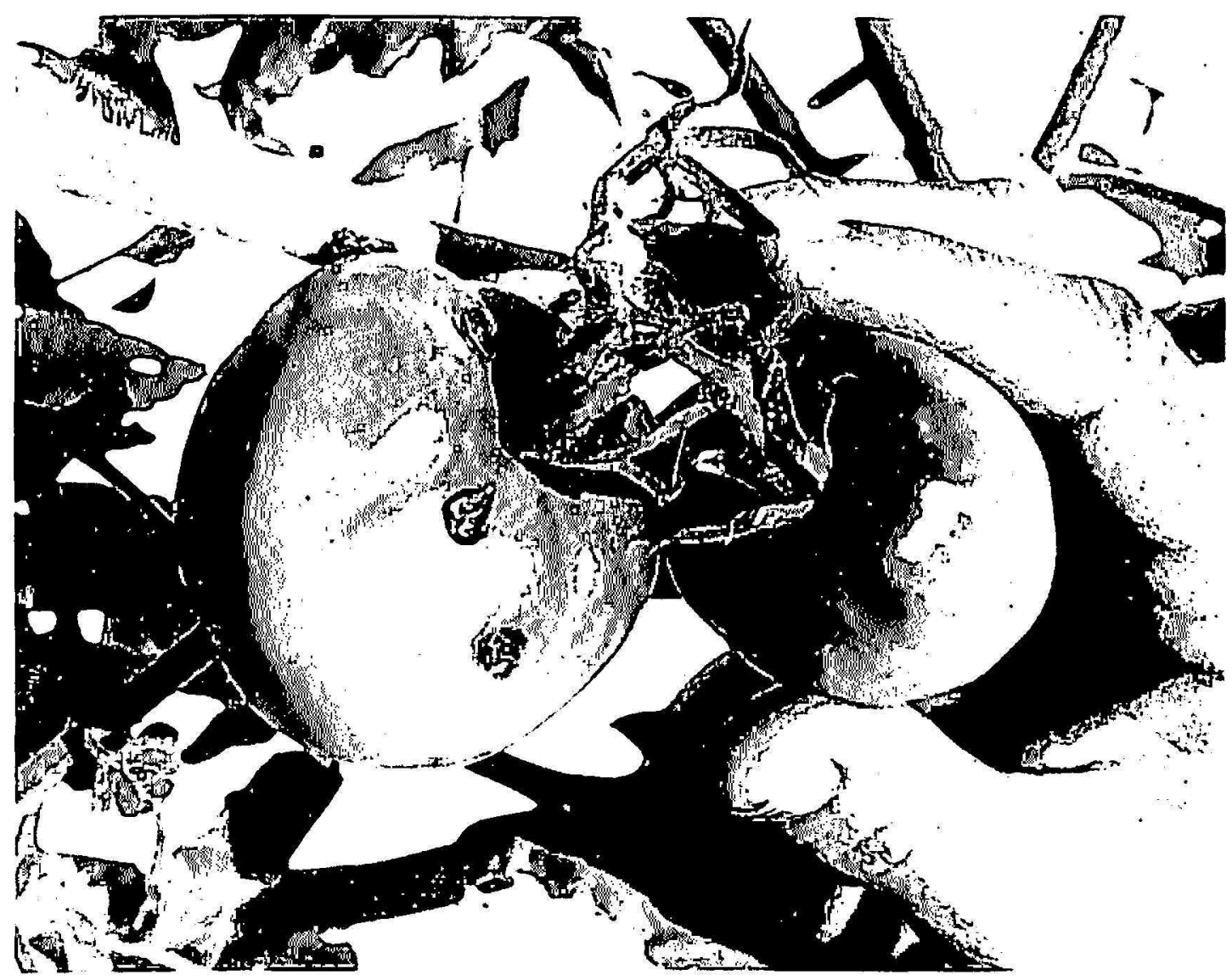

B

Fuc. 1.-A, Sabl, lesions on tomato fruit produced by natural infection in the fichl, a culture from which yielded isolate No. 98; 13, fruit at left shows seab lesions produced hy inoculation with jisblate. No. 98 in a grecnhouse-grown tomato plant; uninoculated fruit at right. 


\section{PLANT INOCULATION TESTS}

Two type cultures of Xanthomonas vesicatoria (Doidge) Dowson, were obtained: 1, A strain isolated from tomato in 1953 by M. P. Starr (No. 11551 of The American Type Culture Collection) and 2, No. 422, a tomato strain from the National Collection of Plant Pathogenic Bacteria, Harpenden, Hertsfordshire, England. These cultures will be referred to as Nos. 11551 and 422 , respectively, while the isolate here reported will be referred to as No. 98.

All three cultures were grown on slants of Nutrient Agar (Difco) for 3 days at $28^{\circ}$ to $30^{\circ} \mathrm{C}$. The bacterial growth was washed with sterile 0.85 percent $\mathrm{NaCl}$ solution ("saline") and the resulting suspension from each separate culture used for inoculations. Inoculations were performed on green tomato fruits and on tomato plants which were bearing green fruit. The fruits were inoculated by lightly pricking with flame-sterilized No. 00 insect pins through a drop of bacterial suspension. They were then placed inside moist chambers. Two circular sheets of moist filter paper were placed inside the chamber, one on the bottom and one on the inside of the cover so as to insure high humidity.

The tomato plants were inoculated in the greenhouse as follows: Some of the fruits were first smeared with bacterial suspension by using a camel'shair brush and then lightly pricked and covered with plastic bags (1). ${ }^{3}$ The whole plant was then sprayed with bacterial suspension by using a small DeVilbiss No. 15 atomizer. The plastic bags on the inoculated fruits were removed after 48 hours. Three plants were inoculated with isolate No. 98 and three with culture No. 11551. Three plants were similarly treated with sterile distilled water to serve as controls.

\section{CULTURAL CHARACTERS}

Colony form, consistency, and pigment production were observed on Nutrient Agar. Observations for pigment production and type of growth were made on sterilized potato plugs. Appearance of growth on nutrient broth was also recorded.

\section{PHYSIOLOGICAL AND COMPARATIVE STUDIES}

Isolate No. 98 was run through a scries of tests together with type cultures Nos. 11551 and 422. Gelatin liquefaction was determined in a medium consisting of 12-percent gelatin in Heart Infusion Broth (Difco). For $\mathrm{H}_{2} \mathrm{~S}$ detection the organisms were grown in a liquid medium of the following composition: Polypeptone (BBL) $10 \mathrm{gm}$., $\mathrm{NaCl} 5 \mathrm{gm}$., and distilled water

${ }^{3}$ Italic numbers in parentheses refer to Literature Cited, p. 310. 
$1,000 \mathrm{ml}$. The medium was distributed in $15 \times 150 \mathrm{~mm}$. cotton-plugged test tubes. After inoculation of the medium a strip of lead acetate paper was inserted and held in position by the cotton plug, without touching the medium. Production of $\mathrm{H}_{2} \mathrm{~S}$ was shown by the intensity of blackening of the paper. Hydrolysis of starch was determined as described by Starr (2). Tests for production of ammonia $\left(\mathrm{NH}_{3}\right)$, action on nitrates, and lipolytic activity, were performed according to the methods described by Dowson (3). For determining the action of the organisms on "sugars", these were incorporated in 1-percent concentration in the basal inorganic medium of Ayers, Rupp, and Johnson (4) with brom thymol blue as an indicator.

\section{SEROLOGICAL TESTS}

Antiscra against cultures Nos. 422,11551 , and 98 were prepared. Rabbits were injected intravenously twice weekly with $1 \mathrm{ml}$. of a saline suspension of 2-day-old cultures of the bacteria grown on Nutrient Agar. Before inoculation the suspensions were heated for 1 hour at $60^{\circ} \mathrm{C}$. in order to kill the bacteria. The suspensions were standardized to approximately 600 million bacteria per milliliter by McFarland's nephelometric method (7).

Twofold dilutions of the three antisera were performed in 0.85-percent saline solution and a tube agglutination test carricd out by adding suspensions of the three organisms separately to each set of dilutions of the three antisera. As a control the same suspensions were tested with equivalent dilutions of an antiserum against Pseudomonas solanacearum E. F. Smith, strain No. 10692 of The American Type Culture Collection and likewise tested with normal rabbit serum.

After adding the bacterial suspensions all tubes were shaken and incubated for 2 hours in a $37^{\circ} \mathrm{C}$. water bath and then overnight at room temperature. The test was then read by examining the tubes in front of a fluorescent lamp for clumping of bacterial cells.

\section{PATTERN OF ANTIBIOTIC SENSI'TIVITY}

Isolate No. 18 and type cultures Nos. 11551 and 422 were grown on nutrient broth for 36 hours at room temperature. The broth cultures were then smeared over the surface of Nutrient Agar plates so that confluent growth would result. Antibiotic Sensitivity Disks (Difeo) were then carefully placed on the surface of the inoculated agar. Disks containing low, intermediate, and high concentrations of the following antibioties were used: Aureomycin, chloromycetin, polymyxin, neomyein, terramycin, and tetracycline (5), 10-, and 30- $\mu$ g. concentrations) and streptomycin and dihidrostreptomycin $(2-, 10-$, and $100-\mu \mathrm{g}$. concentrations). The plates were then incubated for 36 hours at room temperature. 


\section{RESULTS}

From the lesion-bearing tomatoes and spotted leaves pure cultures of a motile, gram-negative bacillus forming yellow, wet colonies on Nutrient Agar were obtained. The yellow color became noticeable after 2 to 3 days incubation at room temperature $\left( \pm 28^{\circ} \mathrm{C}\right)$. All cultures were identical, therefore only one among those from scab spot lesions was used for the comparative studies with type cultures of Xanthomonas vesicatoria.

The isolated culture had very similar characters to those of Xanthomonas vesicatoria type cultures Nos. 422 and 11551. All three gave rise to slowgrowing, yellow, smooth, wet, shiny colonies on Nutrient Agar. Smears from

TABLE 1.-Comparalive reactions of an isolale from tomato-scab lesions and 2 type cullures of Xanthomonas vesicatoria ${ }^{1}$

\begin{tabular}{|c|c|c|c|c|c|c|c|c|c|c|c|c|c|c|c|c|}
\hline $\begin{array}{l}\text { Culture of } \\
\text { Xanthomonas vesicatoria }\end{array}$ & 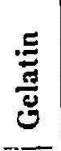 & 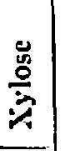 & 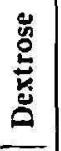 & 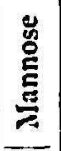 & 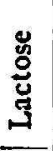 & 总 & 峈 & 农 & 窇 & 宽 & 品 & 总 & $\stackrel{8}{Z}$ & בू & 产 & 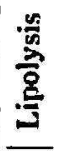 \\
\hline $\begin{array}{c}\text { No. } 11551 \\
\text { (type culture) }\end{array}$ & + & $\mathbf{A}$ & $\mathbf{A}$ & $\mathbf{A}$ & $\mathbf{A}$ & $\mathbf{A}$ & $\mathbf{A}$ & $\mathbf{A}$ & + & - & A & - & - & + & + & + \\
\hline $\begin{array}{c}\text { No. } 422 \\
\text { (type culture) }\end{array}$ & + & A & $\boldsymbol{A}$ & A & $\mathbf{A}$ & A & $\mathbf{A}$ & $\mathbf{A}$ & + & - & $\mathbf{A}$ & - & - & + & + & + \\
\hline $\begin{array}{c}\text { No. } 98 \\
\text { (isolate) }\end{array}$ & + & $\mathbf{A}$ & $\Lambda$ & A & $A$ & $\Lambda$ & $A$ & $\mathbf{A}$ & -2 & - & $\mathbf{A}$ & - & - & + & + & + \\
\hline
\end{tabular}

1 Recorded over a period of 4 weeks. Under gelatin, $+=$ liquefaction; under "sugars", $\mathrm{A}=$ acid but no gas produced; under starch, $+=$ hydrolysis and $-=$ no hydrolysis; under $\mathrm{NO}_{3},-=$ no nitrites present; under $\mathrm{H}_{2} \mathrm{~S},+=\mathrm{H}_{2} \mathrm{~S}$ produced; under $\mathrm{NH}_{3},+=\mathrm{NH}_{3}$ produced.

2 Starch hydrolysis variable within species; see (7).

colonies of the three cultures showed well-defined capsules sorrounding the bacilli when stained by the India-ink method. Growth was yellow and of a gummy consistency on sterilized potato plugs. Inoculated broth was lightly turbid and a yellow ring and faint pellicle were formed in a few days.

The inoculation tests on tomato fruits and plants proved the pathogenicity of isolate No. 98 and furnished additional evidence for its classification as a strain of Xanthomonas 'esicatoria. Within 2 weeks the plants inoculated with suspensions of $\mathcal{X}_{0.9} 98$ and of type culture Yo. 11551 showed leaf and fruit lesions similar to those described by Doidge (1) and Elliot (6) and to the oncs found on the tomato-fruit samples brought to the laboratory (fig. 1,A). The inoculated tomatoes borne on plants showed blackish erateriform lesions with small central blisters. By the 30th day after inoculation the lesions on all inoculated fruits were typical of the scab disease of to- 
mato. The control fruits and/or plants did not show any lesions and remained spot-free throughout the duration of the experiment (35 days). Figure 1,B shows lesions as seen on inoculated tomato fruits in the greenhouse.

TABLE 2.-Agglutination reactions shown by No. 98 isolate and type cultures 428 and 11561 of Xanthomonas vesicatoria ${ }^{1}$

\begin{tabular}{c|c|c|c|c|c}
\hline \multirow{2}{*}{ Culture No. } & \multicolumn{4}{|c|}{ Antisera for cultures- } & $\cdot$ \\
\cline { 2 - 5 } & No. 98 & No. 422 & No. 11551 & No. 10692 & $\begin{array}{c}\text { Normal } \\
\text { serum }\end{array}$ \\
\hline 98 & $1 / 1024$ & $1 / 1024$ & $1 / 1024$ & - & - \\
422 & $1 / 512$ & $1 / 1024$ & $1 / 512$ & - & - \\
11551 & $1 / 1024$ & $1 / 1024$ & $1 / 1024$ & - & - \\
10692 & - & - & - & $1 / 2048$ & - \\
(Pseudomonas solanacearum) & & & & & \\
\hline
\end{tabular}

${ }^{1}$ The dash signs indicate a negative reaction at lowest dilution of serum tested $(1 / 8)$.

2 Highest dilution of serum showing agglutination.

3 Pseudomonas solanacearum antiserum control.

4 Normal rabbit-serum control.

TABLE 3.-In vitro sensitivity of the $S$ strains of Xanthomonas vesicatoria to 8 antibiotics

\begin{tabular}{l|c|c|c|c}
\hline \multicolumn{1}{c|}{ Antibiotic } & $\begin{array}{c}\text { Strains' } \\
\text { Concentration of antibiotic } \\
\text { (micrograms) }\end{array}$ & $\begin{array}{c}\text { Isolate } \\
\text { No. 98 }\end{array}$ & $\begin{array}{c}\text { Isolate } \\
\text { No. 11551 }\end{array}$ & $\begin{array}{c}\text { Isolate } \\
\text { No. 422 }\end{array}$ \\
\hline Aureomycin & $5,10,30$ & VS & VS & VS \\
Chloromycetin & $\mathbf{5 , 1 0 , 3 0}$ & VS & VS & S \\
Streptomycin & $\mathbf{2 , 1 0 , 1 0 0}$ & S & VS & S \\
Dihydrostreptomycin & $2,10,100$ & S & VS & VS \\
Neomycin & $\mathbf{5 , 1 0 , 3 0}$ & SS & S & SS \\
Polymyxin & $5,10,30$ & VS & VS & VS \\
Terramycin & $5,10,30$ & VS & VS & VS \\
Tetracycline & $5,10,30$ & VS & VS & VS \\
\hline
\end{tabular}

${ }^{1}$ Sensitivity of cultures to antibiotics recorded as follows: VS $=$ very sensitive, zone of growth inhibition around 3 concentrations of antibiotic; $S=$ sensitive, inhibition around high and intermediate concentrations; SS = slightly sensitive, inhibition around high concentration only.

The results of comparative studies as to action on gelatin, "sugars", nitrate, production of ammonia, etc., appear in table 1. It may be seen that the three cultures reacted alike except in their ability to hydrolyze starch, which isolate No. 98 failed to do. However, it has been reported 
previously that strains of $X$. vesicatoria differ in their ability to hydrolyze starch ( $(7)$.

The serological (agglutination) tests performed with type cultures Nos. 422,11551 , and isolate No. 98 also gave further evidence of the close similarity between the three cultures. The type cultures and No. 98 were agglutinated equally by any of the antisera prepared against the individual cultures to a titer of $1 / 512-1 / 1024$. No agglutination was observed in any of the dilutions of the Pseudomonas solanacearum antiserum or normal rabbit serum used as controls (table 2). Further, cross-absorption experiments with the three cultures and their antisera (4) gave additional evidence of the serological identity of the cultures.

The results of the antibiotic-sensitivity tests with the three cultures showed a close similarity in their reaction to the various antibiotics. There were only slight differences in their reaction to chloromycetin, streptomycin, dihidrostreptomycin, and neomycin. These results are recorded in table 3.

\section{SUMMARY}

Tomato fruit lesions highly suggestive of bacterial scab yielded a motile, gram-negative, capsulated bacillus, forming wet, yellow colonies on nutrient agar. Pathogenicity tests on tomato as well as physiological, biochemical and agglutination tests identified the organism as Xanthomonas vesicatoria.

\section{RESUMEN}

Un bacilo móvil, negativo al tinte de Gram, capsulado, que forma colonias amarillas de consistencia húmeda en agar nutritivo, se logró aislar de lesiones en tomates muy sugestivas de la mancha bacteriana del tomate. Por medio de pruebas de patogenicidad en tomates, al igual que por el estudio de las reacciones fisiológicas, bioquímicas y serológicas (aglutinación), se probó que este organismo es una estirpe del Xanthomonas vesicatoria.

\section{LITERATURE CITED}

1. Doidge, E. M., A tomato canker, Ann. Appl. Biol. 7 407-30, 1920-21.

2. Starr, M. P., The causal agent of bacterial root and stem disease of guayule, Phylopath. 37 291-300, 1947.

3. Dowson, W. J., Plant Diseases Due to Bacteria, 2nd ed., 231 pp., Cambridge University Press, Cambridge, England, 1957.

4. Manual of Microbiological Methods, Committee on Bacteriological Technic, Society of American Bacteriologists, 315 pp., McGraw-Hill Book Co., Inc., New York, N.Y. 1957.

5. Wadsworth, A. B., Standard Methods of the Division of Laboratories and Research of the New York State Department of Health, composed and printed at the Waverly Press for the Williams \& Wilkins Co., Baltimore, Md., 1927.

6. Elliot, C., Manual of Bacterial Plant Pathogens, 2nd ed. 186 pp., Chronica Botanica Co., Waltham, Mass., 1951.

7. Burkholder, W. H., and Li, C. C., Variations in Phytotomos vesicatoria, Phytopath. 31 753-5, 1941. 